\title{
IMPLEMENTASI KEBIJAKAN MAGANG DAN KONSELING WARGA BERKEBUTUHAN KHUSUS DI SURABAYA
}

\author{
Zainil Ghulam \\ Institut Agama Islam Syarifuddin Lumajang \\ Email:wanlamo9@gmail.com
}

\section{ABSTRACT}

This article discusses counseling and internship programs for people with special needs that are run by the Surabaya City Government. As mandated by the 1945 Constitution, it is the state's obligation to protect the rights of persons with special needs. Including, their rights in the scope of employment. The Surabaya City Government prepared an apprenticeship program for them. Before that, there was a counseling process for each person with special needs. In the implementation of national development aimed at realizing a just and prosperous society based on Pancasila and the 1945 Constitution, people with special needs are part of Indonesian society who also have the same position, rights, obligations and roles. In many cases, apprentices are then recruited by the company. This program is carried out in collaboration with a number of institutions or companies in Surabaya. The theory used in this article is counseling and public policy. While the method used is qualitative, with a literature review approach. As a result, what the Surabaya City Government is doing reinforces the psychological aspects of school graduates with special needs. During the internship, they gained valuable experience and boosted the confidence of each participant. Even if they are not immediately recruited to work at the place, the post-apprenticeship certificate they have, can be their reinforcement when they want to apply to other companies. So, the benefits of this program are in the aspect of training for them, and promotion of the performance of those who are not less than those who do not have some special needs.

Keywords: Public Policy, Counseling, Persons with Special Needs

\section{PENDAHULUAN}

Pemerataan kesejahteraan sosial merupakan syarat mutlak yang dibutuhkan sebagai landasan untuk meraih masa depan yang lebih baik. Pemerataan kesejahteraan sosial juga menjadi kunci bagi bangsa Indonesia untuk dapat keluar dari situasi krisis dan menyongsong era globalisasi. Sebagai salah satu kota besar, Surabaya dituntut menjadi kawasan dengan kesejahteraan sosial yang merata. Dengan cara itu, kota ini bisa menjadi lebih sehat, aman, nyaman untuk ditinggali. Fakta ini disadari betul oleh Pemkot Surabaya. Maka itu, ada banyak program yang dilakukan demi mewujudkan cita-cita itu. Salah satunya, adalah dengan menjalankan Program Magang Disabilitas (Pro Gadis) yang ditangani oleh Dinas Tenaga Kerja. Sebelum menjalankan Pro Gadis, tentu saja, dilakukan konseling pada mereka. Program konseling dan magang bagi penyandang kebutuhan khusus itu adalah upaya memeratakan kesejahteraan masyarakat ${ }^{1}$.

\footnotetext{
${ }^{1}$ Bagian Organisasi Pemerintah Kota Surabaya. 2018. Proposal Pro Gadis. Tersedia di https://organisasi.surabaya.go.id/home/file/pelayanan\%20publik/masuk\%20web/proposal\%20pro\%20gadis.pdf diakses pada 1 Januari 2020
} 
Sebagaimana amanat Undang-Undang Dasar 1945, Pasal 5 ayat 1 dan Pasal 20 ayat 1, sudah menjadi kewajiban negara untuk melindungi hak-hak penyandang kebutuhan khusus. Termasuk, hak-hak mereka di lingkup ketenagakerjaan. Selama ini, ada kesan bahwa mereka mendapat diskriminasi di tengah masyarakat. Stigma itu ingin dilenyapkan oleh Pemerintah Kota Surabaya dengan cara menyiapkan program magang bagi mereka. Sebab, dalam pelaksanaan pembangunan nasional yang bertujuan mewujudkan masyarakat adil dan makmur berdasarkan Pancasila dan Undang-Undang Dasar 1945, penyandang kebutuhan khusus merupakan bagian masyarakat Indonesia yang juga memiliki kedudukan, hak, kewajiban, dan peran yang sama. Selama ini, Pemkot Surabaya sudah sering menjalankan pelatihan untuk penyandang kebutuhan khusus. Karena, mereka memerlukan perhatian khusus. Sebab, sebagian orang masih memandang mereka sebelah mata. Padahal, mereka juga memiliki keistimewaan yang kalau digali, bisa bermanfaat bagi dirinya dan lingkungan sekitar.

Adanya program konseling dan magang bagi penyandang kebutuhan khusus membuka peluang bagi mereka, terlebih, Dinas Tenaga Kerja Surabaya melakukan kerjasama dengan perusahaan-perusahaan. Apa yang dilakukan pemerintah dan pengusaha ini merupakan implementasi amanat undang-undang nomor 13 tahun 2003 tentang ketenagakerjaan. Isinya, tentang kewajiban perusahaan merekrut penyandang kebutuhan khusus untuk berkarya di sana. Dewan Perwakilan Rakyat Daerah (DPRD) Surabaya mendukung program ini. Dengan demikian dapat disimpulkan, masyarakat Surabaya yang terkenal memiliki semangat kekeluargaan yang tinggi ${ }^{2}$, tidak keberatan dengan berlangsungnya kebijakan ini. Pihak DPRD dan pers turut melakukan pengawasan terhadap program ini. Teori yang digunakan dalam penelitian ini adalah kebijakan publik dan konseling. Teori kebijakan publik menjadi landasan pokok, yang kemudian ditopang oleh teori konseling untuk membahas teknis implementasi kegiatan di lapangan.

\section{PERMASALAHAN}

Artikel ini melihat bagaimana kebijakan publik pada program konseling, yang berujung pada program magang, bagi penyandang kebutuhan khusus, diimplementasikan di Surabaya. Secara konseptual, kebijakan publik memunyai tujuan utama guna menyelesaikan problem di semua lapisan masyarakat. Dalam konteks ini, para penyandang kebutuhan khusus. Kebijakan

\footnotetext{
${ }^{2}$ Soedarso, Soedarso, et al. Dinamika Multikultural Masyarakat Kota Surabaya. Jurnal Sosial Humaniora 6.1 (2013): 62-75.
} 
publik bisa berbentuk tatanan, sistem, mekanisme, ataupun regulasi formal yang sudah disahkan pemerintah dengan pertimbangan memberi kebermanfaatan bagi publik ${ }^{3}$.

\section{METODE}

Artikel ini memakai metode kualitatif dengan pendekatan kajian literature atau studi pustaka, yang akrab dikenal dengan sebutan riset pustaka, yang menggunakan sumber perpustakaan untuk memperoleh data ${ }^{4}$. Yang didiskusikan dalam artikel ini adalah kebijakan publik di Surabaya, berupa konseling dan program magang untuk penyandang kebutuhan khusus. Utamanya, mereka yang sudah terpantau Pemerintah Kota Surabaya, melalui sekolahsekolah luar biasa di kota ini. Topik tersebut ditelaah dengan sumber-sumber pustaka dari Pemerintah Kota Surabaya, yang menjelaskan tentang apa yang dilakukan dalam program tersebut. Sumber-sumber lain yang dijadikan acuan adalah literatur yang berkenaan dengan teori kebijakan publik serta teori konseling. Sumber berupa pemberitaan mengenai kebijakankebijakan tersebut juga turut dijadikan rujukan. Semua bahan kepustakaan tadi diramu untuk menunjukkan bagaimana pelaksanaan kebijakan publik ini berjalan selama ini.

\section{PEMBAHASAN}

Terdapat banyak definisi kebijakan publik yang disampaikan para pakar. Salah satu pokoknya, kebijakan publik dianggap sebagai apa yang dilakukan atau tidak dilakukan pemerintah (mulai di level paling bawah hingga paling atas), yang berkenaan dengan isu tertentu bertolak dari kondisi masyarakat ${ }^{5}$. Kebijakan publik dilaksanakan oleh struktur-struktur yang melekat pada pemerintah ${ }^{6}$. Tujuan utama dari kebijakan publik adalah memberi manfaat pada masyarakat di semua lapisan. Kadang kala, satu kebijakan untuk satu lapisan tertentu. Namun semua kebijakan yang diimplementasikan, dipastikan menyentuh semua elemen di masyarakat.

Sementara itu, konseling adalah salah satu bentuk proses komunikasi antar pribadi yang dilakukan dengan intensif7. Tujuannya, konselor bisa memberikan klien (orang yang dikonseling) pencerahan ${ }^{8}$. Dalam konteks topik yang dibahas dalam artikel ini, pihak pemerintah yang menunjuk petugas konselor, memberikan pencerahan pada klien, dalam hal ini penyandang

\footnotetext{
${ }^{3}$ Anderson, James E. 1984. Public Policy Making. New York: Holt, Rinehart and Winston.

${ }^{4}$ Zed, M. (2008). Metode Penelitian Kepustakaan. Jakarta: Yayasan Pustaka Obor Indonesia.

${ }^{5}$ Thomas R. Dye. 1972. Understanding Public Policy. New Jersey : Prentice Hall.

${ }^{6}$ Anderson, James E. 1984. Public Policy Making. New York: Holt, Rinehart and Winston.

${ }^{7}$ Arintoko, Wawancara Konseling Di Sekolah, (Yogyakarta: ANDI, 2011),1

${ }^{8}$ Farid Mashudi, Psikologi Konseling, (Yogyakarta: IRCiSoD, 2012), 19
} 
kebutuhan khusus yang berstatus warga Surabaya, sehubungan dengan apa yang bisa dia kerjakan. Dengan demikian, mereka bisa mendapat tempat magang yang layak, yang berpotensi untuk menjadi tempat mereka bekerja pula. Konseling ini menjadi pintu pembuka dalam program magang, dan tidak memungkinkan berlanjut pada penandatanganan kontrak kerja antara penyandang kebutuhan khusus dan perusahaan. Sebelumnya, kegiatan konseling ini sudah banyak dilakukan oleh Pemerintah Kota Surabaya, sebagai misal, yang dilakukan di Pusat Konseling Anak dan Remaja9. Kegiatan kali ini, berfokus pada anak-anak berkebutuhan khusus.

Ada sejumlah harapan dari implementasi kebijakan ini. Secara umum, bertujuan mewujudkan pemerataan kesejahteraan sosial, sasaran utamanya, penyandang kebutuhan khusus. Melalui program ini, mereka bisa merasa lebih percaya diri, memiliki pengalaman kerja melalui magang, yang tentu menjadi poin plus tatkala mereka melamar pekerjaan di tempat lain. Bahkan yang beruntung, akan langsung direkrut oleh perusahaan tempat dia magang.

\section{Mengaplikasikan Amanat Undang-Undang}

Bila mengacu pada dokumen yang dimiliki Bagian Organisasi Pemkot Surabaya dalam proposal inovasi bertajuk Pro Gadis, program ini sudah dimulai pada $2017^{10}$. Program ini merupakan amanat Undang-Undang nomor 13 tahun 2003. Dalam aturan itu terdapat penjelasan tentang keharusan perusahaan yang ada di Indonesia untuk memberi kesempatan para penyandang kebutuhan khusus untuk bekerja di sana. Negara harus hadir untuk memastikan kalau amanat itu terlaksana dengan baik. Pemkot Surabaya merupakan perwakilan negara di level daerah.

Bila mengacu pada apa yang dikemukakan Bromley dalam Tachjan ${ }^{11}$, kebijakan publik dibentuk oleh tiga level hierarkis, yakni, policy level, organizational level, operational level. Policy level dijalankan oleh pihak yudikatif dan legislatif. Organizational level dilaksanakan oleh pihak eksekutif. Operational level dikerjakan oleh perangkat eksekutif. Perangkat yang dimaksud berbeda-beda pada tiap level. Sebagai contoh, di lingkup Pemerintah Pusat, ada kementerian, di lingkup Pemerintah Provinsi ada Biro, Dinas, dan sebagainya, selanjutnya di lingkup Pemerintah Kabupaten/Kota, ada dinas, bagian, badan, dan sebagainya.

\footnotetext{
${ }^{9}$ Rachman, Rio Febriannur. (2019). Implementasi Kebijakan Pusat Konseling Anak Dan Remaja Di Surabaya. Al-Tazkiah : Jurnal Bimbingan Dan Konseling Islam, 8(2), 77-91.

${ }^{10}$ Bagian Organisasi Pemerintah Kota Surabaya. 2018. Proposal Pro Gadis. Tersedia di https://organisasi.surabaya.go.id/home/file/pelayanan\%20publik/masuk\%20web/proposal\%20pro\%20gadis.pdf diakses pada 1 Januari 2020

${ }^{11}$ Tachjan. Implementasi Kebijakan Publik. Bandung: AIPI, 2006.
} 
Pada tiap tingakatan, kebijakan dilindungi, didasari, dan diwujudkan melalui institutional arrangement atau regulasi yang saha. Dalam konsep kebijakan publik, ada pula yang disebut sebagai pattern interaction, yakni, pola interaksi pelaksana lapangan (street level bureaucrat) dengan kelompok yang menjadi target kebijakan. Dari pola ini, meski bukan satu-satunya pertimbangan, akan bisa dilihat pula efek atau dampak sebuah kebijakan.

Program ini magang dan konseling untuk penyandang kebutuhan khusus ini berada di level Kota Surabaya. Artinya, masing-masing aktor berasal dari pihak yudikatif, legislative, maupun eksekutif dan perangkatnya, di tingkat kota Surabaya.

Pelaksanaan program ini menggunakan model jemput bola. Pihak Pemkot Surabaya, turun ke lapangan untuk melakukan sosialisasi program. Program ini bekerjasama dengan pihak perusahaan-perusahaan yang memang menyediakan kuota magang untuk para penyandang kebutuhan khusus. Sebelumnya, melalui proses jemput bola itu, para penyandang kebutuhan khusus dikonesling terlebih dahulu terkait keinginan mereka untuk magang dan bekerja. Mereka yang terpilih untuk magang, mendapat bantuan uang transport dan uang makan dari Pemkot selama program berlangsung. Fakta menunjukkan, sebagian peserta magang itu langsung direkrut bekerja di perusahaan.

Data yang ada memaparkan bahwa sejak 2019, tiap tahun ada dua puluh orang penyandang kebutuhan khusus mendapat kesempatan magang di perusahaan-perusahaan yang ada di Surabaya. Sebagian dari mereka beruntung karena kemudian direkrut menjadi pegawai. Yang lain, umumnya menunggu hingga ada lowongan pekerjaan di tempat itu. Atau paling tidak, mereka bisa mendapatkan sertifikat atau piagam magang, yang dapat digunakan untuk melamar pekerjaan di tempat lain.

Tahapan program ini antara lain, staf Pemkot Surabaya melakukan sosialisasi ke masyarakat di tiap kecamatan. Ada seleksi awal dari Dinas Tenaga Kerja untuk menentukan peserta program magang dan konseling. Persyaratannya antara lain: kondisi kebutuhan khusus pada level B dan C, tuna wicara atau tuna rungu atau tuna grahita ringan, memiliki ijazah setara SMA dari SLB. Mereka yang lolos seleksi awal akan diajukan ke perusahaan-perusahaan yang menerima tenaga magang dan telah bermitra dengan Pemkot Surabaya. Setelahnya, pihak perusahaan akan menyeleksi mereka. Rekomendasi dari Dinas Tenaga Kerja pasti menjadi pertimbangan. Terlebih, selama ini sudah ada jalinan kerjasama. Terdapat keluaran kongkret setelah munculnya program ini. Antara lain, adanya anggaran APBD sejak 2017 hingga saat ini. 
APBD menunjukkan bahwa program ini dikuatkan oleh Peraturan Daerah yang disahkan oleh legislative bersama eksekutif.

Evaluasi program ini dilaksanakan oleh DPRD Surabaya. Selain itu, ada pengawasan berjenjang. Kepala Dinas Tenaga Kerja sebagai leading sector melakukan pemantauan pada program ini. Yang tentu saja, langsung disupervisi oleh Wali Kota Surabaya. Pantauan juga bisa dilakukan oleh masyarakat secara langsung, sebagai pembayar pajak di Kota Surabaya. Mereka bisa mengakses akun media sosial milik Pemkot Surabaya dan melontarkan kritik, saran, dan masukan terkait program ini.

Tak bisa dimungkiri, terdapat sejumlah kendala saat program ini dijalankan. Antara lain, dalam proses komunikasi antara penerima manfaat dan staf dari Pemerintah Kota. Beberapa penyandang kebutuhan khusus tidak bisa ditangkap keinginan atau aspirasinya oleh staf Pemkot Surabaya. Oleh sebab itu, pihak Pemkot Surabaya memakai jasa penerjemah khusus. Cara lainnya, menggunakan komunikasi secara tertulis.

Kendala lain yang sempoat terjadi di aspek penyampaian panggilan magang atau kerja. Sebab, tidak semua penerima manfaat yang menyandang kebutuhan khusus, memiliki telepon seluler pribadi. Pihak perusahaan diberi pemahaman akan hal ini, sehingga bisa lebih sabar saat melakukan panggilan secara langsung ke rumah-rumah penerima manfaat. Tenggat waktu yang direntangkan cenderung lebih dilonggarkan.

Program ini mencetuskan sejumlah hikmah penting. Yang pasti, adanya kesadaran tentang pentingnya mengasah kepeduliaan. Dengan saling peduli dan saling memberi kesempatan, para penyandang kebutuhan khusus bisa mengekspresikan minat dan bakatnya. Program yang berbasis kepedulian dan kesetaraan masyarakat seperti ini sangat mungkin dilaksanakan dalam porsi dan sasaran yang berbeda. Terlebih, sejauh ini sudah ada jejaring yang bagus antara Pemkot Surabaya dan perusahaan-perusahaan swasta terkemuka. Masyarakat juga sudah mengapresiasi program sejenis ini, yang mana apresiasi itu menjadi bahan bakar bagi Pemkot Surabaya untuk membuat program yang lebih baik lagi.

Perusahaan tempat meganag juga mendapat pelajaran penting. Mereka menjadi mengerti bahwa para penyandang kebutuhan khusus memiliki potensi dan kinerja yang tak kalah dengan mereka yang tidak berkebutuhan khusus. Persepsi semacam ini, lambat laun menyebar di kalangan perusahaan-perusahaan yangada di Surabaya. Sehingga, lowongan rekrutmen bagi penyandang kebutuhan khusus makin meluas. 
Program ini berjalan sejak 2017 di mana prosesnya terus berjalan. Artinya, masyarakat, DPRD, dan Pemkot Surabaya menganggap program ini cocok dan bermanfaat bagi warga Surabaya, terutama penyandang kebutuhan khusus. Fakta ini menegaskan, bahwa di masa yang akan datang, program ini bakal tetap mendapat perhatian.

Fakta di atas memerlihatkan bahwa di waktu-waktu yang akan datang, program ini tetap akan mendapat perhatian baik oleh Pemkot maupun DPRD Surabaya. Dengan demikian, APBD tahunan tetap akan menyiapkan anggaran untuk inovasi ini. Apresiasi positif dari masyarakat, kritik dan saran konstruktif, dan dorongan dari banyak elemen masyarakat, membuat program ini menjadi lebih baik dari hari ke hari. Khususnya, apresiasi yang datang dari para penerima manfaat yang menjadi tolok ukur kepuasaan mereka terhadap program ini.

Yang menarik, bila diperhatikan, program ini tidak sulit untuk direplikasi oleh Pemerintah Daerah lain, asalkan ada sinergitas antara pemangku kepentingan. Selain pihak eksekutif dan legislatif, juga dari pihak perusahaan-perusahaan di daerah itu. Kekompakan menjadi bagian fundamental untuk terwujudnya program yang partisipatoris.

Berdasarkan data dari Dinas Tenaga Kerja Pemkot Surabaya, studi banding untuk mengetahui detail program ini sudah banyak dilakukan oleh Pemda maupun DPRD daerah lain. Pemkot Surabaya selalu bersedia berbagi wawasan dan pengetahuan mengenai programprogram yang sudah dijalankan di Surabaya. Demi kebermanfaatan yang lebih luas di masyarakat.

\section{Sinergitas Demi Mewujudkan Kemaslahatan Umat}

Dalam perspektif Islam, semua program yang dijalankan, khususnya oleh pemerintah, mesti bertujuan agar masyarakat mendapat kemaslahatan umat. Manajemen di bidang-bidang yang berkenaan dengan ekonomi rakyat, termasuk di dalamnya persoalan ketenagakerjaan, mesti berangkat dari keinginan mewujudkan pemerataan kesejahteraan di semua lapisan masyarakat ${ }^{12}$. Dalam program magang dan konseling untuk penyandang kebutuhan khusus ini,

\footnotetext{
${ }^{12}$ Ghulam, Zainil. Membincang Ekonomi Islam dan Kapitalisme. Iqtishduna: Jurnal Ekonomi Islam, Volume 4, Nomor 2, Oktober 2015 Lumajang: Institut Agama Islam Syarifuddin
} 
dilakukan sinergitas baik di internal Pemkot Surabaya maupun dengan pihak eksternal Pemkot Surabaya.

Penjelasan mengenai peran-peran operasional itu antara lain sebagai berikut. Dinas Tenaga Kerja adalah leading sector program. Ditopang oleh pihak kecamatan dan kelurahan sebagai pihak yang diajak berkoordinasi dan memberikan informasi tentang para penyandang kebutuhan khusus di wilayah. Pihak kecamatan dan kelurahan berkoordinasi dengan SekolahSekolah Luar Biasa Karena, salah satu persyaratan dari penyandang kebutuhan khusus yang megikuti program ini adalah adanya ijazah setara SMA dari SLB. Perusahaan-perusahaan di Surabaya diajak untuk bermitra, mereka antara lain adalah Hotel Mercure Grand Mirama, Hotel Majapahit, G-Suite Hotel, Grand Darmo Hotel, PT Generasi Mutiara Bangsa (restoran Carl's Jr), dan Carrefour. Sementara itu, Dewan Perwakilan Rakyat Daerah Surabaya bertindak sebagai pengawas program sedangkan media massa sebagai kontrol sosial.

Sumber daya manusia untuk menjalan program ini berasal dari Dinas Tenaga Kerja dan piihak Kecamatan dan Kelurahan. Juga, berasal dari elemen masyarakat sebagai pihak yang diajak bekerjasama, utamanya, dari pihak Sekolah-Sekolah Luar Biasa dan perusahaanperusahaan mitra. Tahapan konseling, dijalankan oleh pihak Pemkot Surabaya yang memiliki ahli konseling. Sumber pembiayaan program dari APBD Surabaya. Sedangkan alat dan bangunan untuk magang berasal dari perusahaan-perusahaan mitra.

Kebijakan publik bisa ditelaah dengan melihat kondisi masyarakat sebelum dan sesudah keberlangsungan program ${ }^{13}$. Dari sini, dapat dikaji kebermanfaatannya di masyarakat. Bila diperhatikan secara komprehensif, efek positif dari program ini bisa dirasakan oleh masyarakat secara umum, peserta magang, perusahaan tempat magang, Pemkot, dan bagi Kota Surabaya. Dengan program ini, masyarakat umum terasah kepeduliannya satu sama lain, utama kepekaan terhadap keberadaan penyandang kebutuhan khusus. Tali persaudaraan makin kuat karena masyarakat paham kalau pajak yang dibayarkan digunakan untuk program-program pembangunan, yang salah satunya untuk mereka yang berkebutuhan khusus.

Sementara manfaat bagi peserta dair kelompok sasaran, mereka yang berkebutuhan khusus, jelas terasa. Mereka mendapat pengetahuan dari magang, sehingga bisa siap kerja, dan terbuka peluangnya bekerja di perusahaan tempat magang. Mereka mendapat cara

\footnotetext{
${ }^{13}$ Dunn, William N. 2000. Pengantar Analisis Kebijakan Publik. Yogyakarta: Gajah Mada University Press
} 
meningkatkan rasa percaya diri. Dis amping itu, mereka mendapat konseling yang komprehensif yang pasti berguna bagi kehidupannya.

Manfaat bagi perusahaan tentu saja terkait adanya tenaga magang yang bisa membantu operasional perusahaan. Perusahaan juga memeroleh kesempatan untuk menjalankan undangundang, serta mendapat peluang untuk menciptakan tenaga kerja berkualitas dari proses magang tersebut. Perusahaan punya hak untuk merekrut mereka yang sudah magang dan punya talenta bagus di bidang tersebut. Bagi Surabaya sebagai kota, manfaat yang didapatkan adalah terwujudnya kawasan yang ramah untuk siapa pun. Mereka yang berkebutuhan khusus memeroleh kesempatan dan kenyamanan yang sama dengan siapa saja, di kota ini. Selama ini, sudah ada program pelatihan keterampilan kepada mereka yang berkebutuhan khusus oleh Dinas Tenaga Kerja dan Dinas Sosial. Program magang dan konseling melengkapi apa yang sudah dikerjakan itu, dengan Dinas Tenaga Kerja yang menjadi leading sector.

\section{Magang Sebagai Awal Penguatan Ekonomi}

Ajaran Islam memiliki semangat Al-‘adalah Al-iqtisadiyah atau munculnya pemerataan dan keadilan ekonomi. Keadilan ekonomi memiliki hubungan erat dengan distribusi pendapatan dan atau kekayaan ${ }^{14}$. Islam mengarahkan agar kekayaan dan atau penghasilan yang layak bisa diperoleh oleh semua orang. Jadi, tidak hanya beredar dalam satu kelompok hartawan yang sejak zaman nenek moyang mereka memiliki akses kapital ${ }^{15}$. Semua materi, baik yang sifatnya harta, uang maupun produk yang bisa dikonsumsi, harus beredar di masyarakat secara adil, terlebih di dalamnya ada fungsi sosial ${ }^{16}$. Selama ini, Pemerintah Kota Surabaya berupaya melakukan pemberdayaan ekonomi yang lintas kelompok ${ }^{17}$. Sehingga, semua warga bisa mendapat keadilan ekonomi. Termasuk, melalui penyediaan fasilitas-fasilitas pendukung ${ }^{18}$. Di sisi yang sama, program magang dan konseling yang dilakukan oleh Pemerintah Kota Surabaya memastikan, bahwa kelompok penyandang kebutuhan khusus memeroleh kesetaraan di aspek ekonomi, melalui pengadaan akses pekerjaan bagi mereka. Seperti diketahui, selepas magang, mereka memiliki peluang untuk memeroleh pekerjaan layak di tempat yang dimaksud.

\footnotetext{
${ }^{14}$ Al-Quran Surah Al Hasyr (59) ayat 7

${ }^{15}$ Ruslan Abdul Ghofur Noor, “Kebijakan Distribusi Ekonomi Islam dalam Membangun Keadilan Ekonomi Indonesia”, Islamica, 6, No. 2, (Maret 2012), 316-328

${ }^{16}$ M. Quraish Shihab, Tafsir al-Mishbah, Vol. 14 (Jakarta: Lentera Hati, 2002), 112-113.

${ }^{17}$ Rachman, Rio Febriannur. Optimalisasi Media Digital Berbasis Kemaslahatan Umat dalam Program Pahlawan Ekonomi Surabaya. IQTISHODUNA: Jurnal Ekonomi Islam, [S.I.], v. 8, n. 2, p. 273-292, oct. 2019

${ }^{18}$ Rio Febriannur Rachman. (2019). Pengembangan Industri Kreatif Berbasis Media Digital di Surabaya dalam Perspektif Islam. KOMUNITAS, 10(2), 157-176.
} 
Program magang dan konseling ini terbukti memberikan dampak bagi masyarakat, sehingga dapat dilihat perbedaan antara sebelum kebijakan dan sesudah kebijakan dilaksanakan. Artinya, kebijakan tersebut sudah bisa diukur implementasinya, bertolak dari titik tolak awal ide kebijakan dicetuskan berikut tujuan-tujuan yang ingin dicapai ${ }^{19}$. Pemerintah, di mana pun levelnya baik di kabupaten kota, provinsi, maupun pusat, memang memiliki peran sentral dalam mengatur aspek perekonomian agar terjadi pemerataan ${ }^{20}$. Termasuk di dalamnya, melalui program perluasan kesempatan bekerja, yang pintu awalnya bisa melalui program magang.

Di lain pihak, program ini memiliki keselarasan dengan Tujuan Pembangunan Berkelanjutan yang dicanangkan oleh Perserikatan Bangsa-Bangsa ${ }^{21}$. Antara lain, di poin No Poverty atau pemberantasan kemiskinan. Program ini jelas membuka kesempatan lapangan pekerjaan bagi masyarakat, terutama bagi para penyandang kebutuhan khusus.

Program ini juga selaras dengan tujuan mencapai Good Health and Well-Being atau keterjaminan kesehatan dan hidup yang sejahtera. Oleh karena lepangan pekerjaan tercipta, hidup mereka yang menjadi sasaran program pasti akan lebih sejahtera. Program ini juga selaras dengan aspek Decent Work and Economic Growth atau ketersediaan pekerjaan yang layak dan pertumbuhan ekonomi. Program ini juga ikut mengurangi kesenjangan (Reduce Inequality) antara mereka yang tidak berkebutuhan khusus dan yang berkebutuhan khusus. Berkat program ini, dua kelompok tadi akhirnya memiliki peluang yang sama untuk menjalani hidup di Surabaya. Bisa jadi, pada satu titik, pengelompokkan seperti itu akan tergerus dengan sendirinya pada suatu kelak. Yang tak kalah penting, program ini juga menjamin keberlanjutan kota dan komunitas di dalamnya (Sustainable Cities and Communities). Melalui program ini, para penyandang kebutuhan khusus memiliki ruang untuk tetap bisa menikmati segala fasilitas dan kenyamanan yang ada di Kota Surabaya.

Sementara itu, Konferensi Tingkat Tinggi (KTT) Dunia untuk pembangunan sosial (World Summit on Social Development) di Kopenhagen, Denmark, 6-12 Maret 1995, memaparkan tiga dimensi yang menjadi sorotan dalam pembangunan, yakni, dimensi kemiskinan, dimensi ketenagakerjaan, dan dimensi integrasi sosial ${ }^{22}$. Program magang dan konseling bagi penyandang kebutuhan khusus jelas memiliki keselarasan dengan tiga dimensi tersebut.

\footnotetext{
${ }^{19}$ Winarno, Budi. Kebijakan Publik:Teori dan Proses. (Yogyakarta: Med Press, 2007)

${ }^{20}$ M. Arif Hakim, "Peran Pemerintah Dalam Mengawasi Mekanisme Pasar Dalam Perspektif Islam". Iqtishadia, Vol 8 , No. 1, (Maret 2015), 19-40

${ }^{21}$ Perserikatan Bangsa-Bangsa. 2015. About the Sustainable Development Goals. Tersedia di https://www.un.org/sustainabledevelopment/sustainable-development-goals/. Diakses pada 11 September 2018

${ }^{22}$ Edi Suharto. Analisis Kebijakan Publik. (Bandung: CV Alfabeta, 2014)
} 
Program ini menyentuh dimensi kemiskinan karena sejak awal mencegah kemiskinan dengan upaya penciptaan keahlian melalui magang. Magang juga merupakan pintu awal masuk ke lapangan pekerjaan, yang artinya, punya korelasi dengan dimensi ketenagakerjaan. Pada gilirannya, terdapat sinergitas atau integritas sosial, karena program ini menggerus kesenjangan dan perbedaan yang ada antara mereka yang berkebutuhan khusus dan yang tidak berkebutuhan khusus. Ajaran Islam mengatur tentang keseimbangan, misalnya, tentang kebutuhan individual dan sosial ${ }^{23}$. Manusia adalah makhluk sosial yang tidak boleh mengabaikan sekitar, seseorang perlu tetap perhatian pada kondisi sosialnya, sehingga keseimbangan tetap terwujud dalam kehidupan, dan keadilan dapat dirasakan oleh semua lapisan masyarakat ${ }^{24}$. Problem sosial menjadi tanggungjawab pemerintah di setiap level.

\section{PENUTUP}

Kebijakan publik memunyai maksud menjadi solusi di masyarakat atas persoalan yang terjadi. Kebijakan publik dilakukan pemerintah untuk menciptakan tatanan, sistem, mekanisme, ataupun aturan yang dilegalisasikan untuk tujuan tertentu, demi mensejahterakan masyarakat. Implementasi program magang dan konseling untuk penyandang kebutuhan khusus dijalankan dengan azas kesetaraan, kekeluargaan serta kebersamaan. Cita-cita dari program ini adalah menggerus diskriminasi atau pembedaan antara mereka yang tidak berkebutuhan khusus dan yang berkebutuhan khusus. Model seperti ini selaras dengan kaidah dalam Islam yang humanis secara naluri manusia, artinya tidak ada individualitas maupun merasa diri lebih sempurna dibandingkan orang lain, apapun alasannya.

Para intelektual Islam klasik maupun kontemporer kerap menegaskan soal maqâsid alsyarî'ah yang merupakan konsep yang fokus pada perlindungan agama, jiwa, akal, keturunan, dan harta tiap anggota masyarakat. Adanya program ini jelas melindungi jiwa dan akal penyandang kebutuhan khusus. Karena, mereka merasa setara dengan orang lain yang tidak berkebutuhan khusus. Pada gilirannya, harta mereka terjaga, karena mereka bisa memeroleh penghasilan dengan baik melalui bekerja di tempat yang semestinya tanpa diskriminasi. Mereka juga bisa lebih percaya diri untuk membangun rumah tangga dan memiliki keturunan. Bila empat

\footnotetext{
${ }^{23}$ Mursal \& Suhadi, “Implementasi Prinsip Islam dalam Aktivitas Ekonomi: Alternatif Mewujudkan Keseimbangan Hidup", Jurnal Penelitian, 9, No. 1, (Februari 2015), 67-92

${ }^{24}$ Heri Junaidi \& Cholidi Zainuddin, "Prinsip-Prinsip Ekonomi Islam: Sebuah Kajian Awal”, Jurnal Muamalah, 3 No. 1 (Juni 2017), 1-14
} 
aspek tersebut sudah terjamin, keyakinan mereka terhadap agama sudah barang tentu makin menebal.

Suatu kebijakan publik, seperti implementasi program ini, bisa dianalisis secara objektif di aspek kebermanfaatannya. Data lapangan menunjukkan kebermanfaatan dari program ini, antara lain, penyandang kebutuhan khusus yang merasa senang, pengusaha yang puas karena kinerja para penyandang kebutuhan khusus ternyata tidak berbeda dengan yang lain, serta keterbukaan perusahaan-perusahaan pada program ini terus berlanjut. Artinya, kebijakan publik ini berjalan dengan baik. Terlebih, program ini juga selaras dengan tujuan pembangunan berkelanjutan yang digagas oleh Perserikatan Bangsa-Bangsa.

Yang tak kalah menarik, terdapat mekanisme kemitraan, antara Pemkot Surabaya selaku regulator dengan perusahaan-perusahaan. Artinya, muncul kebijakan yang bersifat partisipatoris, mereka yang non-pemerintah pro-aktif mendukung kebijakan ini. Terdapat sinergitas. Mengacu pada perspektif Islam, Tuhan Yang Mahaesa melalui kalam-kalam suci di AlQur'an memerintahkan manusia untuk berjuang menegakkan kebenaran dan menjalankan rencana kebaikan dalam barisan teratur seakan-akan mereka seperti suatu bangunan yang tersusun kokoh, serta saling menopang satu sama lain.Sinergitas, kebersamaan, dan persatuan ini selaras dengan salah satu riwayat yang memerintahkan agar kaum muslimin berdiri di dalam lingkaran Al-Jamaah atau kelompok kebaikan.

\section{REFERENSI}

Al-Quran Surah Al Hasyr (59) ayat 7

Anderson, James E. 1984. Public Policy Making. New York: Holt, Rinehart and Winston.

Arintoko, Wawancara Konseling Di Sekolah, (Yogyakarta: ANDI, 2011),1

Bagian Organisasi Pemerintah Kota Surabaya. 2018. Proposal Pro Gadis. Tersedia di https://organisasi.surabaya.go.id/home/file/pelayanan\%2opublik/masuk\%20web/proposal\%2opro \%20gadis.pdf diakses pada 1 Januari 2020

Dunn, William N. 2000. Pengantar Analisis Kebijakan Publik. Yogyakarta: Gajah Mada University Press

Edi Suharto. Analisis Kebijakan Publik. (Bandung: CV Alfabeta, 2014)

Farid Mashudi, Psikologi Konseling, (Yogyakarta: IRCiSoD, 2012), 19

Ghulam, Zainil. Membincang Ekonomi Islam dan Kapitalisme. Iqtishduna: Jurnal Ekonomi Islam, 
Volume 4, Nomor 2, Oktober 2015 Lumajang: Institut Agama Islam Syarifuddin

Heri Junaidi \& Cholidi Zainuddin, “Prinsip-Prinsip Ekonomi Islam: Sebuah Kajian Awal”, Jurnal Muamalah, 3 No. 1 (Juni 2017), 1-14

M. Arif Hakim, "Peran Pemerintah Dalam Mengawasi Mekanisme Pasar Dalam Perspektif Islam”. Iqtishadia, Vol 8, No. 1, (Maret 2015), 19-40

M. Quraish Shihab, Tafsir al-Mishbah, Vol. 14 (Jakarta: Lentera Hati, 2002), 112-113.

Mursal \& Suhadi, “Implementasi Prinsip Islam dalam Aktivitas Ekonomi: Alternatif Mewujudkan Keseimbangan Hidup”, Jurnal Penelitian, 9, No. 1, (Februari 2015), 67-92

Perserikatan Bangsa-Bangsa. 2015. About the Sustainable Development Goals. Tersedia di https://www.un.org/sustainabledevelopment/sustainable-development-goals/. Diakses pada 11 September 2018

Rachman, Rio Febriannur. (2019). Implementasi Kebijakan Pusat Konseling Anak Dan Remaja Di Surabaya. Al-Tazkiah : Jurnal Bimbingan Dan Konseling Islam, 8(2), 77-91.

Rachman, Rio Febriannur. (2019). Pengembangan Industri Kreatif Berbasis Media Digital di Surabaya dalam Perspektif Islam. KOMUNITAS, 10(2), 157-176.

Rachman, Rio Febriannur. Optimalisasi Media Digital Berbasis Kemaslahatan Umat dalam Program Pahlawan Ekonomi Surabaya. IQTISHODUNA: Jurnal Ekonomi Islam, [S.I.], v. 8, n. 2, p. 273-292, oct. 2019

Ruslan Abdul Ghofur Noor, "Kebijakan Distribusi Ekonomi Islam dalam Membangun Keadilan Ekonomi Indonesia”, Islamica, 6, No. 2, (Maret 2012), 316-328

Soedarso, Soedarso, et al. Dinamika Multikultural Masyarakat Kota Surabaya. Jurnal Sosial Humaniora 6.1 (2013): 62-75.

Tachjan. Implementasi Kebijakan Publik. Bandung: AIPI, 2006.

Thomas R. Dye. 1972. Understanding Public Policy. New Jersey : Prentice Hall.

Winarno, Budi. Kebijakan Publik:Teori dan Proses. (Yogyakarta: Med Press, 2007)

Zed, M. (2008). Metode Penelitian Kepustakaan. Jakarta: Yayasan Pustaka Obor Indonesia. 